\title{
ANALISIS KEAKTIFAN PENGELOLAAN HUTAN KEMASYARAKATAN DI AREAL HKM BANGKENG BUKIT DI DESA BONTONYELENG, KECAMATAN GANTARANG, KABUPATEN BULUKUMBA
}

\author{
(Analysis of the Performance of Sustainable Forest Management in areal HKm \\ Bangkeng Bukit in Bontonyeleng Village, Gantarang district, Bulukumba Regency) \\ Yusran'), Muhammad Alif K.S.1) Adrayanti Sabar1),, Asfar Mirna2) \\ 1)Staf Pengajar, Fakultas Kehutanan, Universitas Hasanuddin, Makassar \\ 2)Mahasiswa, Laboratorium Kebijakan dan Kewirausahaan Kehutanan, Universitas \\ Hasanuddin, Makassar; \\ email : yusranforest@yahoo.com
}

\begin{abstract}
Community forest is a forest management concept that is for poor citizens who live in and around a forest area and rely their lives on the use of forest resources, IUPHKm which is forest farmer groups of Bukit Indah in Bontonyeleng village, Gantarang district, Bulukumba regency. After running five years, the monitoring of the implementation of the Community forest General Plan document is necessary in terms of institutional and business management aspects. To assess whether community forest management is truly active management or hollow management, it is analyzed by comparing management planning and its implementation on production component, distribution, and institution aspects with obeservation method, interview and document analysis so that the management of HKm Bukit Bangkeng is categorized as active forest management due to the implementation of activity the dominant field that has been done.
\end{abstract}

Kata Kunci : Community forest, Forest farmer groups of Bukit Indah, Active forest management.

Intisari

Hutan kemasyarakatan adalah konsep pengelolaan hutan yang diperuntukkan bagi warga miskin yang tinggal di dalam dan sekitar kawasan hutan dan mengandalkan kehidupan mereka pada penggunaan sumber daya hutan, IUPHKm yang merupakan kelompok tani hutan Bukit Indah di desa Bontonyeleng, kabupaten Gantarang, kabupaten Bulukumba. Setelah berjalan lima tahun, pemantauan implementasi dokumen Rencana Umum hutan kemasyarakatan diperlukan dalam hal aspek kelembagaan dan manajemen bisnis. Untuk menilai apakah pengelolaan hutan rakyat benar-benar manajemen aktif atau manajemen kosong, dianalisis dengan membandingkan perencanaan pengelolaan dan implementasinya pada komponen produksi, distribusi, dan aspek kelembagaan dengan metode obeservasi, wawancara dan analisis dokumen sehingga pengelolaan $\mathrm{HKm}$ Bukit Bangkeng dapat dilakukan. dikategorikan sebagai pengelolaan hutan aktif karena pelaksanaan kegiatan bidang dominan yang telah dilakukan.

Kata Kunci: Hutan kemasyarakatan, kelompok tani hutan Bukit Indah, Pengelolaan hutan aktif. 


\section{PENDAHULUAN}

Konsep Pembangunan Hutan Berbasis Masyarakat (PHBM) merupakan konsep pembangunan hutan yang diharapakan dapat mengakomodir kebutuhan dan kesejahteraan masyarakat di sekitar hutan (Nandini, 2013).

Salah satu bentuk pembangunan hutan berbasis masyarakatadalah Hutan Kemasyarakatan (HKm). Menurut Moeliono dkk, (2015). HKm hanya diberlakukan di kawasan hutan lindung, dan hutan produksi yang tidak dibebani hak atau izin dalam pemanfaatan hasil hutan, dimana kawasan tersebut menjadi sumber mata pencarian masyarakat setempat. Izin Usaha Pemanfaatan Pengelolaan HKm (IUPHKm) diberikan jangka waktu 35 tahun dan diperpanjang sesuai dengan hasil evaluasi setiap 5 tahun.

Secara nasional pelaksanaan konsep HKm telah dikembangkan pada 22 provinsi dengan luas keseluruhan sekitar 448.217 $\mathrm{Ha}$, yang terdiri dari areal usulan penetapan wilayah $\mathrm{HKm}$ seluas 162.112,91 $\mathrm{Ha}$, areal pembangunan $\mathrm{HKm}$ seluas $208.327 \mathrm{Ha}$, areal kerja seluas $55.420 \mathrm{Ha}$ dan areal yang diberi ijin sementara seluas $62.357 \mathrm{Ha}$. Total kelompok masyarakat yang terlibat pada kegiatan HKm adalah 519 kelompok (Media DAS, 2007). Pemerintah Kabupaten Bulukumba di Sulawesi Selatan adalah salah satu kabupaten yang paling awal secara aktif mempromosikan HKm. Berdasarkan Surat Keputusan Menteri Kehutanan (sekarang Kementrian Lingkungan Hidup dan Kehutanan atau KLHK) Nomor SK.363/Menhut-II/2011 menetapkan areal seluas 2.256 Ha sebagai areal kerja HKm, lebih dari separuh lahan tersebut telah mendapatkan Izin Usaha Pengelolaan Hutan Kemasyarakatan (IUPHKm) (Tangngareng \& Ridha, 2016).
Pada tahun 2012 terbit keputusan

Bupati Bulukumba Nomor SK 533/XII/2012 tentang pemberian IUPHKm kepada 8 Kelompok Tani Hutan, salah satu KTH yang mendapatkan IUPHKm yaitu KTH Bukit Indah yang terletak di wilayah administrasi Desa Bontonyeleng, Kecamatan Gantarang, Kabupaten Bulukumba luas areal $127 \mathrm{Ha}$, dengan luas lahan $\mathrm{HKm}$ (per orang) 1-1,5 $\mathrm{Ha}$ (Hadi dkk, 2013; Tangngareng \& Ridha, 2016). Setelah berjalan selama 5 tahun, evaluasi terhadap program ini diperlukan monitoring mengenai pengimplementasian dokumen Rencana Umum HKm tersebut dari segi aspek kelola kelembagaan dan kelola usaha. Untuk menilai apakah pengelolaan hutan Kemasyarakatan benar active management ataukah hollow management.

Penelitian ini akan menilai keaktifan pengelolaan hutan tersebut dengan membandingkan perencanaan dan implementasinya pada tiga isu awal yaitu komponen produksi, distribusi, dan institusi. Tujuan dari penelitian ini adalah menganalisiskeaktifan pengelolaanHutan Kemasyarakatan pada aspek produksi, distribusi, dan institusi lokal pengelolaan $\mathrm{HKm}$ Bangkeng Bukit desa Bontonyeleng.

\section{METODE PENELITIAN}

\section{Metode Pelaksanaan Penlitian}

Pemilihan lokasi didasari karena daerah Bulukumba merupakan ssalah satu sentral pembangunan Hutan Kemasyarakatan di Sulawesi Selatan.

Data-data yang dikumpulkan untuk keperluan penelitian digolongkan menjadi dua, yaitu data primer diperoleh dari hasil wawancara mendalam dengan pengelola hutan kemasyarakatan dalam hal ini lembaga pendamping lokal terkait penyusunan dokumen RU-HKm dan RO$\mathrm{HKm}$ dan para petani pemegang IUPHKm sebagaipihak yang mengimplementasikan secara langsung dokumen tersebut serta 
mengidentifikasi jenis unit usaha yang tengah berjalan dalam pengelolaannya. Data sekunder diperoleh dari lembaga/instansi yang terkait dengan penelitian, termasuk kondisi umum wilayah, peraturan-peraturan pengelolaan hutan kemasyarakatan, data unit usaha yang dikelola oleh KTH bukit indah serta informasi lainnya yang terkait dengan penelitian ini.

Dalam melaksanakan penelitian ini digunakan beberapa metode, diantaranya sebagai berikut:

a. Observasi, peneliti akan mengamatii secara langsung kondisi di lapangan terkait dengan pelaksanaan kegiatan $\mathrm{HKm}$ di Desa Bontonyeleng, aktivitas yang dilakukan, serta kondisi anggota kelompok tani hutan.

b. Wawancara, dilakukan untuk mendapatkan informasi terkait pengimplementasian dokumen RU$\mathrm{HKm}$ dan $\mathrm{RO}-\mathrm{HKm}$ yang telah terlaksana ataupun belum serta alasannya.

c. Penelusuran dokumen/literature, Data dan informasi yang dimaksud untuk mendukung penelitian yaitu dokumen Rencana Umum Hutan Kemasyarakatan (RU-HKm), Rencana Oprasinonal Hutan Kemasyarakatan, Rencana Operasional Hutan Kemasyarakatan (RO-HKm) dan dokumen Pengelolaan Hutan Kemasyarakatn.

\section{Analisis Data}

Analisis yang digunakan dalam penelitian ini yaitu analisis dokumen. Analisis ini merupakan sebuah teknik menguhubungkan antara dokumen kebijakan (peraturan perundangan dan peraturan formal lainnya) dengan fokus kajian (Bungin, 2007). Dokumen yang dimaksud dalam hal ini yaitu dokumen formal maupun dokumen informal lainnya yang berhubungan dengan rencana pengelolaan Hutan Kemasyarakatan di Desa Bontonyeleng dengan implementasi di lapangan.

Kegiatan pengelolaan Hutan Kemasyrakatan mempunyai kriteria yang harus dijadikan landasan dalam mengelola hutan dengan baik (Yadav, dkk. 2003). Berikut 8 kriteria yang dapat dijadikan acuan untuk membandingkan keadaan yang sebenarnya di lapangan, yaitu:

1) Pengelolaan hutan yang baik dapat dimaksimalkan kegunaannya.

2) Pengguna mampu membuat perencanaan pengelolaan sesuai dengan kebutuhan yang diperlukan.

3) Sistem manajemen yang bijaksana dalam pendirian blok yang berotasi.

4) Dilakukan penanaman untuk rehabilitasi lahan terbuka.

5) Memberi perlakuan (penjarangan, pemangksan dan pembersihan) untuk regenerasi spesies yang diinginkan.

6) Rasional pemanfaaatan hasilhutan, ekstraksi dan pemanfaaatan kayu cacat, jatuh/tumbang dan mati yang dapat dimanfaatkan untuk hal lain seperti dijadikan kayu bakar.

7) Melakukan pembibitan terhadap spesies tertentu.

8) Menjual hasil kayu yang berlimpah.

\section{HASIL DAN PEMBAHASAN}

Setelah membaca dokumen perencanaan Hutan Kemasyarakatan yang meliputi Rencana Umum Hutan Kemasyarakatan, Rencana Oprasional Hutan Kemasyarakatan, Profil Kelompok Tani Hutan Kemasyarakatan Bukit Indah, dan membandingkannya dengan hasil

Observasi dilapangan, maka tingkat realisasi kegiatan pengelolaan $\mathrm{HKm}$ 
Bangkeng Bukit dari aspek produksi, distribusi dan intitusi adalah sebagai berikut :

Rencana pengelolaan $\mathrm{HKm}$ Bangkeng

Bukit pada aspek produksi, di dalam dokumen RU-HKm da RO-HKm, dapat dilihat pada Tabel 1.

Tabel 1. Aspek Produksi dalam dokemen formal RU-HKm dan RO-HKm

\begin{tabular}{|c|c|c|c|c|c|}
\hline No. & Rencana & Dok & Imen & Kegiatan & Realisasi \\
\hline & & $\begin{array}{l}\text { RU- } \\
\mathrm{Hkm}\end{array}$ & $\begin{array}{l}\mathrm{RO}- \\
\mathrm{HKm}\end{array}$ & & \\
\hline 1. & $\begin{array}{l}\text { Pengembangan } \\
\text { usaha } \\
\text { hasil hutan kayu }\end{array}$ & $\checkmark$ & $\checkmark$ & $\begin{array}{l}\text { 1. Persiapan } \\
\text { 2. Penanaman } \\
\text { 3. Pemeliharaan } \\
\text { a. Penyiangan } \\
\text { b. Penyulaman } \\
\text { c. Pempukan } \\
\text { 4. Pemanenan }\end{array}$ & $\begin{array}{l}\text { Belum melakukan pemanenan, } \\
\text { karena terkandala izin, Penabangan } \\
\text { dilakukan setelah tanaman berumur } \\
11 \text { tahun dan sistem tebang pilih } \\
\text { dengan diameter } 40 \mathrm{~cm}\end{array}$ \\
\hline 2. & $\begin{array}{l}\text { Pengembangan } \\
\text { usaha } \\
\text { hasil hutan bukan } \\
\text { kayu }\end{array}$ & $\checkmark$ & $\checkmark$ & $\begin{array}{l}\text { 1. Penanaman MPTS } \\
\text { 2. Pemeliharaan } \\
\text { a. Penyiangan } \\
\text { b. Penyulaman } \\
\text { c. Pemupukan } \\
\text { 3. Pemungutan } \\
\text { 4. Usaha lebah madu } \\
\text { 5. usaha gula semut dan } \\
\text { kakao }\end{array}$ & $\begin{array}{l}\text { Kegiatan penanaman dilakukan pada } \\
\text { tahun ke } 1-5(2010-2014) \text { dan } \\
\text { dilanjutkan tahun ke 6-10 (2015-2019) }\end{array}$ \\
\hline 3. & $\begin{array}{l}\text { Rencana Produk } \\
\text { usaha lebah madu }\end{array}$ & $\checkmark$ & - & $\begin{array}{l}\text { 1. Pengadaan Koloni } \\
\text { 2. Pemeliharaan Koloni } \\
\text { 3. Pemananena } \\
\text { 4. Pasca Panen }\end{array}$ & $\begin{array}{l}\text { Kegiatan dilakukan pada tahun ke } 1 \\
\text { setelah itu tidak } \\
\text { lanjutkan karena koloni berpindah dari } \\
\text { lokasi }\end{array}$ \\
\hline 4. & $\begin{array}{l}\text { Rencana } \\
\text { pengembangan } \\
\text { usaha jasa } \\
\text { lingkungan }\end{array}$ & $\checkmark$ & - & $\begin{array}{l}\text { 1. Survai } \\
\text { 2. Pembangunan embun } \\
\text { (empan darat) } \\
\text { 3. Usaha Peternak sapi } \\
\text { 4. Industri markisa dan } \\
\text { mabel } \\
\text { 5. wisata alam } \\
6 \text { pembuatan kolan kalen } \\
\text { dan pengembangan lebah } \\
\text { madu }\end{array}$ & $\begin{array}{l}\text { Kegiatan dilakukan pada tahun ke } 1 \\
\text { setelah itu tidak } \\
\text { lanjutkan karena koloni berpindah dari } \\
\text { lokasi }\end{array}$ \\
\hline 5. & $\begin{array}{l}\text { Pengembangan } \\
\text { usaha pemenfaatan } \\
\text { kawasan }\end{array}$ & $\checkmark$ & $\checkmark$ & $\begin{array}{l}\text { 1. evaluasi } \\
\text { 2. penetapan lahan } \\
\text { 3. penanaman } \\
\text { 4. pemeliharaan }\end{array}$ & $\begin{array}{l}\text { Kegiatan dilakukan pada tahun ke 1-5 } \\
(2010-2014) \text { dan tahun ke } 6-10 \\
(2015-2019)\end{array}$ \\
\hline
\end{tabular}

Usaha pengembangan hasil hutan kayu di $\mathrm{HKm}$ Bangkeng Bukit belum berproduksi karena belum ada izin. Pengelolaan HKm Bangkeng Bukit pada hasil hutan bukan kayu berupa gula aren jika dilihat dari aspek produksinya anggota KTH Bukit Indah aktif melakukan kegiatan produksi.

\section{Aspek Institusi Lokal}

HKm Bangkeng Bukit di Desa Bontonyeleng dikelola bersama dalam kelompok tani hutan Bukit Indah. Kelompok tani yang dibentuk atas dasar 
kesamaan kepentingan, kesamaan kondisi lingkungan (sosial, ekonomi, sumberdaya) keakraban dan keserasian yang dipimpin oleh seorang ketua. Jumlah anggota kelompok tani yaitu 74 orang. Dalam pengelolaan $\mathrm{HKm}$ tidak terlepas dari adanya kendala Upaya yang dilakukan untuk meminimalisir masalah dalam pengelolaan lahan maka setiap anggota kelompok tani menyepakati adanya sanksi/hukuman yang diberikan kepada anggota kelompok yang melanggar kewajibannya.

Pengelolaan HKm Bangkeng Bukit juga memerlukan jaminan keberlangsungan atau kontinuitas, sementara ijin pengelolaan hutan negara diberikan selama 35 tahun. Oleh karenanya, aturan internal kelompok tani Bukit Indah juga menetapkan sistem hak kelola waris pada masing-masing lahan garapan. Aturan tersebut memberikan ketentuan kepada anggota kelompok tani hutan untuk memberikan hak kelola hutan negara yang dimilikinya kepada anak atau cucu mereka jika yang bersangkutan telah meninggal dunia.

Pelaksanaan aturan internal, yang telah diatur di Anggaran Dasar dan Anggaran Rumah Tangga yang disepakati oleh kelompok, pelaksanaannya cukup efektif dan dipatuhi oleh anggota. Hal ini terjadi karena ketua kelompok tani Bukit Indah merupakan tokoh yang dihormati oleh penduduk sekitar. Selain itu, adanya dorongan penguatan kelembagaan dari Dinas Kehutanan dan pendampingan yang intensif dari pihak Lembaga Swadaya Masyarakat SCF (Sulawesi Community Foundation) menjadikan pengelolaan kelembagaan cukup memberikan peran yang signifikan.

\section{Aspek Distribusi}

Pengelolaan HKm Bangkeng Bukit di Desa Bontonyeleng pada aspek distribusi menunjukkan bahwa untuk hasil hutan berupa kayu belum ada yang terdistribusi, dikarenakan dalam dokumen $\mathrm{RU}-\mathrm{HKm}$ telah diatur bahwa penebangan dilakukan setelah tanaman berumur 11 tahun, dengan sistem tebang pilih dan diameter meninamal $40 \mathrm{~cm}$. Sedangkan untuk hasil hutan bukan kayu yang telah terdistribusi yaitu kakao, gula aren, kemiri, kelapa, pisang, durian, nangka, merica.

Petani di $\mathrm{HKm}$ Bangkeng Bukit menjual hasil produksi hasil hutan bukan kayu ke konsumen secara langsung di pasar dan melalui perantara pedagang lokal (tengkulak). Pedagang lokal yang membeli hasil produk petani berasal dari beberapa desa di Kecamatan Gantarang diantaranya Desa Bukit Harapan, Desa Bontonyeleng, Desa Anrang dan Desa Bukit Tinggi. Harga HHBK biasanya langsung ditentukan oleh tengkulak. Sedangkan untuk penjualan langsung, sistem penjualan yang dilakukan yaitu pengrajin menjual langsung ke pasar dan hasil penjualan tersebut dibagi secara adil dengan pemilik.

Pengelolaan HKm Bangkeng Bukit pada hasil hutan bukan kayu berupa gula aren jika dilihat dari aspek distribusinya anggota KTH Bukit Indah aktif melakukan kegiatan distribusi disebabkan tingginya permintaan konsumen terhadap produk aren yang dikelola oleh anggota KTH Bukit Indah. Pada sistem distribusinya petani menjual hasil produksi ke konsumen secara langsung di pasar dan melalui perantara pedagang lokal, walaupun menjual langsung ke pasar akan lebih menguntungkan namun dengan menjual melalui perantara akan meminimalkan pengeluaran biaya transportasi.

Keaktifan Pengelolaan
Kemasyarakatan


berdasarkan Yadav dkk (2003). Hasil

dibawah ini :

analisis diperlihatkan pada Tabel 2

Tabel 2. Hasil analisa keaktifan pengelolaan HKm Bangkeng Bukit

\begin{tabular}{|c|c|c|c|}
\hline No & $\begin{array}{l}\text { Active Forest } \\
\text { Management }\end{array}$ & Hasil Observasi Lapangan & Alasan \\
\hline 2 & $\begin{array}{l}\text { Pengguna mampu membuat perencanaan } \\
\text { pengelolaan sesuai dengan kebutuhan yang } \\
\text { diperlukan. }\end{array}$ & $\begin{array}{l}\text { Perencanaan yang dibuat pada saat } \\
\text { pengusulan hutan kemasyarakatan sangat } \\
\text { baik, karena menyusaikan dengan kondisi } \\
\text { dilpangan. }\end{array}$ & $\begin{array}{l}\text { Perencanaan pembagian blok } \\
\text { kawasan hutan kemsyarakatan } \\
\text { telah terealisasi. Terdapat } 4 \text { blok } \\
\text { yang telah dibagi dalam } \\
\text { pengelolaan yaitu blok buhun } \\
\text { ritonko, dunie dan lian patundugan } \\
\text { dan blok jennae }\end{array}$ \\
\hline 3 & $\begin{array}{l}\text { Sistem manajemen yang bijaksana dalam } \\
\text { pendirian blok yang berotasi. }\end{array}$ & Sistem manejemen sejauh ini baik. & $\begin{array}{l}\text { Pembagian blok sudah sesuai } \\
\text { dengan kondisi dilapangan }\end{array}$ \\
\hline 4 & $\begin{array}{l}\text { Dilakukan penanaman untuk rehabilitasi } \\
\text { lahan terbuka }\end{array}$ & $\begin{array}{l}\text { Belum ada penanaman untuk rehabilitasi lahan } \\
\text { terbuka, belum melekukan kegiatan produksi } \\
\text { dalam bentuk kayu }\end{array}$ & $\begin{array}{l}\text { Belum ada aktivitas penanaman } \\
\text { untuk rehabilitasi lahan terbuka } \\
\text { karena tidak ada kegiatan } \\
\text { penebangan. }\end{array}$ \\
\hline 6 & $\begin{array}{l}\text { Rasional pemanfaaatan hasil hutan, ekstraksi } \\
\text { dan pemanfaaatan kayu cacat, } \\
\text { jatuh/tumbang dan mati yang dapat } \\
\text { dimanfaatkan untuk hal lain seperti dijadikan } \\
\text { kayu bakar. }\end{array}$ & Kegiatan ekstraksi pemanfaatan kayu tumbang & $\begin{array}{l}\text { Beberapa petani yang bertempat } \\
\text { tinggal di luar kawasan HKm } \\
\text { Bangkeng Bukit memanfaatkan } \\
\text { kayu tumbang sebagai kayu bakar }\end{array}$ \\
\hline 7 & $\begin{array}{l}\text { Melakukan pembibitan terhadap spesies } \\
\text { tertentu ( jati putih, sengon, mahoni dan } \\
\text { cengekeh) }\end{array}$ & $\begin{array}{l}\text { Pembibitan ( jatih putih, sengon, mahoni dan } \\
\text { cengekeh) }\end{array}$ & $\begin{array}{l}\text { Status hutan kemasyarakatan } \\
\text { merupakan hutan produksi }\end{array}$ \\
\hline
\end{tabular}

Perbandingan hasil analisis dokumen RU$\mathrm{HKm}$ dan RO-HKm dan observasi di lapangan Hutan Kemasyarakatan Bangkeng Bukit jika dibandingkan dengan kriteria active forest management yang diadopsi dari penelitian Yadav dkk (2003), maka pengelolaan HKm Bangkeng Bukit dikategorikan active forest management. Hal ini disebabkan implementasi kegiatan dilapangan dominan terlaksana.
Berdasarkan 8 kriteria keaktifan hanya 5 kriteria yang terlaksana.

Hubungan kriteria tingkat keaktifan dengan aspek produksi, dapat dilihat bahwa pengelolaan produksi hasil hutan kayu belum terealisasi dengan baik, hal ini dikarenakan dalam dokumen RU-HKm telah diatur bahwa penebangan dilakukan setelah tanaman berumur 11 tahun, 
dengan sistem tebang pilih dan diameter meninamal $40 \mathrm{~cm}$, sedangkan pengelolaan produksi hasil hutan bukan kayu yang telah terealisasi yaitu produksi gula aren. Kriteria tingkat keaktifan dengan aspek distribusi, dapat dilihat bahwa pengelolaan menjual hasil hutan kayu yang berlimpah belum terealisasi, karena tidak ada izin kegiatan penebangan dan telah diatur dalam dokumen RU-HKm. Kriteria tingkat keaktifan yang berkaitan dengan aspek institusi yaitu perencanaan pengelolaan dan sistem manajemen yang bijak, apabila dilihat dari perencanaan yang diatur didalam dokumen RU-HKm terdapat 4 blok yang telah dibagi dalam pengelolaan yaitu blok buhun ritonko, dunie dan lian patundugan dan blok jennae.

\section{KESIMPULAN}

Berdasarkan hasil penelitian maka disimpulkan bahwa pengelolaan $\mathrm{HKm}$

\section{DAFTAR PUSTAKA}

Bungin, B. 2007. Penelitian Kualitatif: Komunikasi, Ekonomi, Kebijakan Publik, dan IImu Sosial. Kencana Prenama Media Group. Jakarta.

Hadi, P.A., Sethiawan B., Markum., \& Suyono. 2013. Pengembangan Wadah Belajar Pengelolaan Hutan Berbasi Masyarakat (WBPHBM). Mataram.

Nandini, R. 2013, Evaluasi Pengelolaan Hutan Kemasyarakatan (Hkm) Pada Hutan Produksi dan Hutan Lindung di Pulau Lombok. Jurnal Penelitian Hutan Tanaman Vol. 10 No. 1: 43-55

Moeliono M., Mulyana A., Adnan H., Yuliani EL., Manalu P., \& Balang. 2015. Ijin Saja Tidak Cukup:
Bangkeng Bukit, berdasarkan kriteria aspek produksi, distribusi, dan institusi termaksud kategori Active Forest Management, khusus pada aspek produksi hasil hutan kayu anggota KTH Bukit Indah tidak aktif melakukan kegiatan produksi, sedangkan untuk hasil hutan bukan kayu anggota KTH Bukit Indah aktif melakukan kegiatan produksi.

\section{SARAN}

Berdasarkan hasil penelitian maka disarankan kepada Pemerintah Desa dan Kelompok Tani Hutan Bukit Indah perlu memperhatikan dalam penyusanan dokumen RU-HKm dan RO-HKm untuk meningkatkan hasil hutan kayu, dan lebih cermat melihat potensi Hutan Kemasyarakatan khususya untuk hasil hutan kayu yang kemudian dikelola dan dikembangkan bersama dengan masyarakat Desa Bontonyeleng umumnya dan masyarakat sekitar hutan khususnya

Belajar dari Hutan Kemasyarakatan (HKM) di Bulukumba. Brief 50. Bogor, Indonesia.

Media DAS. 2007. Perubahan Paradigma Pembangunan Kehutanan : Kerjasama Pusat dan Daerah Sangat Diperlukan. Edisi 07/Tahun I/Desember 2007. Jakarta

Tangngareng, T \& Ridha, M. 2016. Pelaksanaan Pengelolaan HKM Di Desa Bukit Indah, Bulukumba: Batasan dan Kemungkinan. Bhumi Vol.2 No.2:194-208 
Yadav, N. P., Dev, O. P., SpringateBaginski, O., \& Soussan, J. 2003.

Forest management and utilization under community forestry. Journal of Forest and Livelihood, 3(1),

37-50 